\title{
Tau oligomers accumulation sensitizes prostate cancer cells to docetaxel treatment
}

\author{
Stefano Martellucci ${ }^{1,2} \cdot$ Letizia Clementi $^{1} \cdot$ Samantha Sabetta $^{1} \cdot$ Paola Muzi $^{3} \cdot$ Vincenzo Mattei $^{2,4} \cdot$ Mauro Bologna $^{3}$. \\ Adriano Angelucci ${ }^{1}$ (b)
}

Received: 12 October 2020 / Accepted: 11 March 2021 / Published online: 2 April 2021

(c) The Author(s) 2021

\begin{abstract}
Purpose Human tau is a highly dynamic, multifunctional protein expressed in different isoforms and conformers, known to modulate microtubule turnover. Tau oligomers are considered pathologic forms of the protein able to initiate specific protein accumulation diseases, called tauopathies. In our study, we investigated the potential association between autophagy and tau oligomers accumulation and its role in the response of prostate cancer cells to docetaxel.

Methods We evaluated in vitro the expression of tau oligomers in prostate cancer cell lines, PC3 and DU145, in presence of autophagy inhibitors and investigated the role of tau oligomers accumulation in resistance to docetaxel treatment.

Results Tau protein was basally expressed in prostate cancer lines as several monomeric and oligomeric forms. The pharmacologic inhibition of autophagy induced in cancer cells the accumulation of tau protein, with a prevalent expression of oligomeric forms. Immunofluorescence analysis of untreated cells revealed that tau was visible mainly in dividing cells where it was localized on the mitotic spindle. Inhibition of autophagy determined an evident upregulation of tau signal in dividing cells and the presence of aberrant monoastral mitotic spindles. The accumulation of tau oligomers was associated with DNA DSB and increased cytotoxic effect by docetaxel.

Conclusions Our data indicate that autophagy could exert a promoting role in cancer growth and during chemotherapy facilitating degradation of tau protein and thus blocking the antimitotic effect of accumulated tau oligomers. Thus, therapeutic strategies aimed at stimulating tau oligomers formation, such as autophagy inhibition, could be an effective adjuvant in cancer therapy.
\end{abstract}

Keywords Tau oligomer $\cdot$ Autophagy $\cdot$ Prostate Cancer $\cdot$ Docetaxel $\cdot$ Cancer Therapy $\cdot$ Mitosis

\section{Introduction}

Tau is a heat-stable, highly dynamic, protein known to bind to and stabilize microtubules (Wang and Mandelkow 2016; Kellogg et al. 2018). Tau exists in different isoforms and

Adriano Angelucci

adriano.angelucci@univaq.it

1 Department of Biotechnological and Applied Clinical Sciences, University of L'Aquila, Via Vetoio, 67100 L'Aquila, Italy

2 Biomedicine and Advanced Technologies Rieti Center "Sabina Universitas", 02100 Rieti, Italy

3 Department of Life, Health and Environmental Sciences, University of L'Aquila, 67100 L'Aquila, Italy

4 Department of Experimental Medicine, "Sapienza" University, 00161 Rome, Italy folds with specific conformers which are considered the etiologic factors of protein accumulation diseases collectively known as tauopathies (Fitzpatrick et al. 2017). Besides the six splice variants generated from a single gene through alternative splicing of exons 2,3 and $10(0,1,2 \mathrm{~N}$ multiplied by $\mathrm{C}$-terminal microtubule-binding repeats $3 \mathrm{R}$ and $4 \mathrm{R}$ ), and three major conformations described, phosphorylation and other post-translational modifications contribute to generate a very complicated array of protein expression.

Tau accumulation into intracellular tangles has long been associated with neurodegenerative disease, including Alzheimer's disease, Parkinson's disease, progressive supranuclear palsy, corticobasal degeneration and frontotemporal dementias. More recently new data are unveiling new physiopathologic aspects of tau. For example, it was demonstrated that also non-fibrillar soluble aggregates and oligomers of tau have a pathogenic activity (Lasagna-Reeves et al. 2012). 
In fact, soluble oligomers can self-aggregate to form large insoluble toxic fibrils, playing a crucial role for neurodegenerative diseases onset and acting as seeds in the misfolding and the propagation of the disease. In particular, hyperphosphorylated tau tends to be spontaneously misfolded and rapidly aggregated into oligomers enriched in $\beta$-sheet content (Ward et al. 2012). At the same time, available evidence suggests that the accumulation of the smaller, soluble and dynamic oligomers is also associated with cellular stress and mitochondria dysfunction (Shafiei et al. 2017). Treatment with curcumin derivatives able to counteract tau oligomer aggregation pathways, protected neuroblastoma SH-SY5Y cells from tau oligomer-induced toxicity, suggesting that the aggregation state of toxic tau oligomeric species could be an effective therapeutic target (Lo Cascio et al. 2019). In agreement, the use of specific antibodies able to reduce levels of tau oligomers has been effectively used in the therapeutic protection against tau pathologies in vivo (Castillo-Carranza et al. 2015).

The cytotoxicity associated with tau accumulation prompts to investigate the importance of physiologic clearance mechanism in tau homeostasis. Indeed, increasing data are indicating a protective role for protein clearance mechanisms in different cell models and not only in neurodegenerative diseases. Protein quality control via ubiquitin/proteasome system and autophagy are particularly important for the timely removal of aggregated forms of pathogenic proteins, including tau (Ciechanover and Kwon 2015). Dysregulation of autophagy is frequently seen in tauopathies, and some authors indicate in this situation a driving pathogenic role (Menzies et al. 2017; Silva et al. 2019). Hyperphosphorylated tau co-localizes with autophagic vesicles in patient with tauopathies and increased levels of the lysosomal components were reported in the same patients, indicating the activation of a recovery mechanism (Piras et al. 2016).

In general, autophagy is increasingly considered an important mechanism in the maintenance of cellular homeostasis. In fact, beside serving as a stress response in presence of increased energy or structural demand, autophagic activity serves to dispose of unwanted organelles or proteins or during normal cell metabolism. In fact, autophagy targets include aberrant mitochondria but also several protein aggregates (Kaur and Debnath 2015).

The hypothesis that tau was expressed prevalently in neurons justifies why tau biology has been investigated almost only in the nervous central system. Indeed, tauopathies are described as neurodegenerative diseases. However, tau role is increasingly attracting attention also in other pathologies, including non-neuronal cancers. Tau expression in cancer cell lines and tissues is highly heterogeneous, with negative cases frequently reported. The principal human tissues for which has been reported a measurable level of tau expression are breast, prostate, gastric, colorectal pancreatic tissues and the same for corresponding tumors (Li et al. 2013; Huda et al. 2017; Wang et al. 2013; Jimeno et al. 2007; Souter and Lee 2009; Gargini et al. 2019). Although the significance of high expression heterogeneity also in these tissues is unknown, some data suggest a potential association with cancer progression and prognosis. In fact, tau is an independent prognostic marker in prostate cancer and tau expression was increased in metastatic tissue compared with primary breast cancer cells (Schroeder et al. 2019; Matrone et al. 2010). In addition, tau expression in cancer cells can predict response to chemotherapy, and in particular to taxanes. Tau-negative expression has been repetitively related to a favourable response to paclitaxel treatment in the breast, ovarian gastric and bladder cancer (Rouzier et al. 2005; Smoter et al. 2013; Mimori et al. 2006; Wosnitzer et al. 2011). In addition, other authors, after observing a higher cancer incidence in families affected by mutated tau and tauopathies, indicated in dysfunctional tau a novel risk factor for cancer (Rossi et al. 2018).

These initial suggestions recommend further investigation about the possibility that tau expression could represent an advantage for cancer progression in some contexts, and that tau homeostasis could be a therapeutic target. Starting from this hypothesis we evaluated the expression of tau in prostate cancer cell lines and the role of tau oligomers accumulation in cells treated with docetaxel.

\section{Materials and methods}

\section{Cell lines}

PC3, a human prostate carcinoma cell line established from bone metastasis (ECACC, \#90112714), was cultured in Coon's Modified Ham's medium supplemented with $10 \%$ fetal bovine serum, $2 \mathrm{mM}$ glutamine $100 \mathrm{IU} / \mathrm{mL}$ penicillin and $100 \mu \mathrm{g} / \mathrm{mL}$ streptomycin. DU145 a human prostate carcinoma cell line established from brain metastasis (ATCC, HTB-81) was cultured in Eagle's Minimum Essential Medium (EMEM) supplemented with $10 \%$ fetal bovine serum, $2 \mathrm{mM}$ glutamine $100 \mathrm{IU} / \mathrm{mL}$ penicillin and $100 \mu \mathrm{g} / \mathrm{mL}$ streptomycin. All cell lines underwent testing for mycoplasma by culture isolation, Hoechst DNA staining and PCR, together with culture testing for contaminant bacteria, yeast and fungi. Authentication procedures included species verification by DNA barcoding and identity verification by DNA profiling. Human cell lines were analyzed by PCR of short tandem repeat sequences within chromosomal microsatellite DNA (STR-PCR). Cells were plated at a density of $10^{4}$ cells $/ \mathrm{cm}^{2}$, incubated in $5 \% \mathrm{CO}_{2}$ at $37^{\circ} \mathrm{C}$ and recovered after different times of incubation. At the endpoint, cells were harvested, centrifuged and aliquots of cell suspensions were counted using a Neubauer hemocytometer chamber. 
Dead cells were assessed by the trypan blue dye (SigmaAldrich, St. Louis, MO, USA) exclusion test. Authophagy inhibitors, chloroquine and bafilomycin A1, and inhibitor of tau oligomers, methylene blue were purchased from Sigma-Aldrich.

\section{Western blot}

Cancer cells were processed for protein extraction with cell lysis buffer containing $0.1 \%$ Triton X-100, $10 \mathrm{mM}$ Tris-HCl (pH 7.5), $150 \mathrm{mM} \mathrm{NaCl}, 5 \mathrm{mM}$ EDTA, and supplemented with $1 \mathrm{mM} \mathrm{Na}_{3} \mathrm{VO}_{4}$ and $75 \mathrm{U}$ of aprotinin (Sigma-Aldrich), and incubated for $20 \mathrm{~min}$ at $4{ }^{\circ} \mathrm{C}$. The cell lysate was centrifuged for $10 \mathrm{~min}$ at $1300 \mathrm{~g}$ to eliminate nuclei and large cellular debris. After protein concentration analysis by Bradford Dye Reagent assay (Bio-Rad, Hercules, CA, USA), the whole cell lysate of each sample was subjected to $10 \%$ sodium-dodecyl sulphate polyacrilamide gel electrophoresis (SDS-PAGE) together with prestained protein molecular markers sharpmass VII (Euroclone, Milan, Italy). The proteins were electrophoretically transferred onto nitrocellulose membranes Amersham protran $0.2 \mu \mathrm{m}$ (Cytiva Europe, Freiburg, Germany) for $90 \mathrm{~min}$ at $350 \mathrm{~mA}$. Membranes were blocked for $1 \mathrm{~h}$ at RT with $10 \%$ nonfat milk in Tris Buffered Saline (Bio-Rad) at pH 7.4 containing $20 \mathrm{mM}$ Tris, $500 \mathrm{mM} \mathrm{NaCl}$ and supplemented with $0.05 \%$ Tween 20 (Bio-Rad), and probed for $1 \mathrm{~h}$ at RT with primary antibodies anti-tau (D1M9X), anti-pH2AX and anti-GAPDH (all from Cell Signaling Technology, Danvers, MA, USA), anti- $\beta$-Tubulin (Cell Signaling Technology), anti-cyclin $\beta 1$ (Santa Cruz Biotechnology, CA, USA), anti-beclin 1 (2A4, Cell Signaling Technology) according to dilution suggested by the manufacturer. Protein bands were visualized after $1 \mathrm{~h}$ of incubation with horseradish peroxidase (HRP)-conjugated anti-rabbit IgG or anti-mouse IgG (Cell Signaling Technology) at RT, and chemiluminescence reaction, using the ECL Western detection system (Amersham, Buckinghamshire, UK). Chemiluminescent signals were acquired by Chemidoc XRS system and digitally elaborated with Imagelab software (Bio-Rad).

\section{Knockdown of tau protein by siRNA}

Cells were seeded at a density of $5 \times 10^{4}$ cells $/ \mathrm{mL}$ in a 6 well-plate and in standard culture conditions. Twentyfour hours after seeding, a pool of four different siRNA constructs (Qiagen, Valencia, CA, USA) was diluted in $200 \mu \mathrm{l}$ culture medium without serum to obtain a final concentration of $20 \mathrm{nM}$. Ten $\mu \mathrm{l}$ of HiPerFect Transfection Reagent/Qiagen) were added to the diluted siRNA, vortexing. Samples were incubated for 5-10 $\mathrm{min}$ at room temperature then added drop-wise onto the cells. The cells were incubated with the transfection complexes under their normal growth conditions and gene silencing was checked after $48 \mathrm{~h}$ by western blot. As a negative control, cells were transfected with $20 \mathrm{nM}$ scrambled siRNA (AllStars Negative Control—Qiagen).

\section{Immunofluorescence}

Cells were seeded at a density of 10,000 cells $/ \mathrm{cm}^{2}$ on glass coverslips pretreated with $30 \mu \mathrm{g} / \mathrm{mL}$ poly-L lysine to promote adherence. At the end of the treatment cells were fixed with $4 \%$ paraformaldehyde (Euroclone) for $10 \mathrm{~min}$ at $4{ }^{\circ} \mathrm{C}$ and permeabilized for $10 \mathrm{~min}$ at RT with $0.1 \%(\mathrm{v} / \mathrm{v})$ Triton X-100 (Bio-Rad). After washing, cells were incubated with anti-tau (D1M9X) anti-pH2AX or anti- $\beta$-Tubulin (all from Cell Signaling Technology), for additional $45 \mathrm{~min}$. After washing with PBS, cells were incubated for $30 \mathrm{~min}$ at RT with Alexa Fluor 594/488-conjugated secondary antibodies (Jackson ImmunoResearch Laboratories, West Grove, PA, USA). Controls were performed by omitting the primary antibody. Slides were mounted with ProLong Gold antifade mounting medium with DAPI (Cell Signaling Technology). Finally, cells were observed with Zeiss Axio Vert. A1 fluorescence microscope (Zeiss, Jena, Germany) and acquired images were digitally elaborated with a modular image-processing and analysis software (Zen 2012 SP2 Blue Edition).

\section{Flow cytometry analysis}

Flow cytometry was used to analyse the expression of tau and LAMP1 in cancer cells and for the analysis of cell cycle. For protein expression analysis, cells at the endpoint were fixed with $4 \%$ paraformaldehyde and permeabilized by $0.1 \%$ (v/v) Triton X-100. After washing, cells were incubated with primary antibodies rabbit anti-tau (D1M9X) and antiLAMP-1 (eBioH4A3, FITC, eBioscience) for $1 \mathrm{~h}$ at $4{ }^{\circ} \mathrm{C}$, followed by Alexa Fluor 594-conjugated anti-rabbit antibody (Jackson ImmunoResearch Laboratories, West Grove, PA, USA) for additional $30 \mathrm{~min}$. All samples were analysed with BD Accuri C6 Flow cytometer (BD Technologies, Durham, $\mathrm{NC}$, USA) equipped with a blue laser $(488 \mathrm{~nm})$ and red laser $(640 \mathrm{~nm})$. At least 20,000 events were acquired for each experimental point. Cell cycle analysis by cytometer was performed following standard staining protocol. Briefly, at the endpoint cells were washed twice in phosphate buffered saline (PBS) and fixed in $70 \%$ ethanol for $10 \mathrm{~min}$ at $4{ }^{\circ} \mathrm{C}$. Then, cells were washed twice with PBS, resuspended in $0.5 \mathrm{~mL}$ PBS, $50 \mu \mathrm{L}$ RNase A ( $5 \mu \mathrm{g} / \mathrm{mL})$ (Sigma-Aldrich), and stained with $0.5 \mathrm{~mL}$ of $100 \mathrm{mg} / \mathrm{mL}$ propidium iodide (Sigma-Aldrich) in PBS. Cells were incubated for $30 \mathrm{~min}$ at room temperature in the dark and analysed for DNA 
Fig. 1 Analysis of combination treatment with docetaxel and autophagy inhibitors. a PC3 and DU145 cells were treated for $72 \mathrm{~h}$ with two concentrations of docetaxel (DTX, 0.5 and $5 \mathrm{nM}$ ) alone or in combination with two different autophagy inhibitors, bafilomycin (Bfl $1 \mu \mathrm{M}$ ) and chloroquine ( $\mathrm{Chl} 20 \mu \mathrm{M}$ ); the number of viable cells were measured and the mean of five different measures with SDs was reported in the histogram. The differences between DTX alone and combination treatments resulted statistically significant (Student's $t$ test, $p<0.05)$ and are indicated in the histogram with symbols: (*) DTX0.5 + Chl vs DTX0.5; (**) DTX0.5+ Bfl vs DTX0.5; (\#) DTX5 + Chl vs DTX5; (\#\#) DTX5 + Bfl vs DTX5. b PCa cells were treated for $72 \mathrm{~h}$ with docetaxel alone (DTX, $0.5 \mathrm{nM}$ ) or in combination with bafilomycin $(\mathrm{Bfl} 1 \mu \mathrm{M})$ and the number of events in cell cycle phases was measured by cytofluorimetry. The experiment was repeated three times and means plus SDs were reported in the histogram, while representative profiles obtained from PC3 cells analysis are shown in the bottom panel. Asterisk indicates a value $p<0.05$ (Student's $t$ test) between number of cells in G2/M phase between $\mathrm{DTX}+\mathrm{Bfl}$ and DTX alone. c After $72 \mathrm{~h}$ of treatment performed as described in panel (a), PC3 and DU145 cells were evaluated for the presence of dead cells. The histogram shows the means and SDs from five different experiments and the statistically significant differences between DTX alone and combination treatments are indicated by asterisks (Student's $t$ test, $p<0.05$ )

content and the fluorescence intensity was measured using the Accuri C6 cytometer.

\section{Data analysis and statistics}

All the statistical procedures were performed by GraphPad Prism Software Inc. (San Diego, CA, USA). Data are expressed as means \pm standard deviations (SDs) of at least three independent experiments. The statistical significance between measure series was calculated with parametric Student $t$ test and $p$ values of less than 0.05 .

\section{Results}

\section{Autophagy protects from docetaxel cytotoxicity}

To evaluate the potential interaction between docetaxelinduced cytotoxicity and autophagy, PCa cell lines, PC3 and DU145, were treated with bafilomycin A1 (Bfl) or chloroquine $(\mathrm{Chl})$ in combination with different concentrations of docetaxel ( 0.5 and $5 \mathrm{nM})$. Bfl and $\mathrm{Chl}$ are common and potent inhibitors of cellular autophagy interfering in the formation of autolysosome (Vinod et al. 2014; Maclean et al. 2008). When viable cells were counted after $72 \mathrm{~h}$ of treatment, a significant decrement in the number of cells were recorded in presence of the combination docetaxel plus autophagy inhibitor respect to all other experimental conditions (Fig. 1a). This effect was observed both in PC3 and DU145 cells and demonstrated a similar trend for bafilomycin and chloroquine. The analysis of the cell cycle by cytofluorimetry revealed that the antitumoral effect of the a

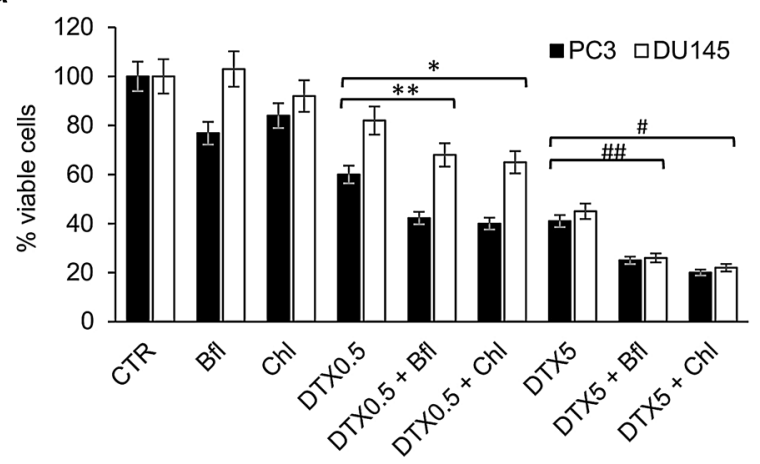

b
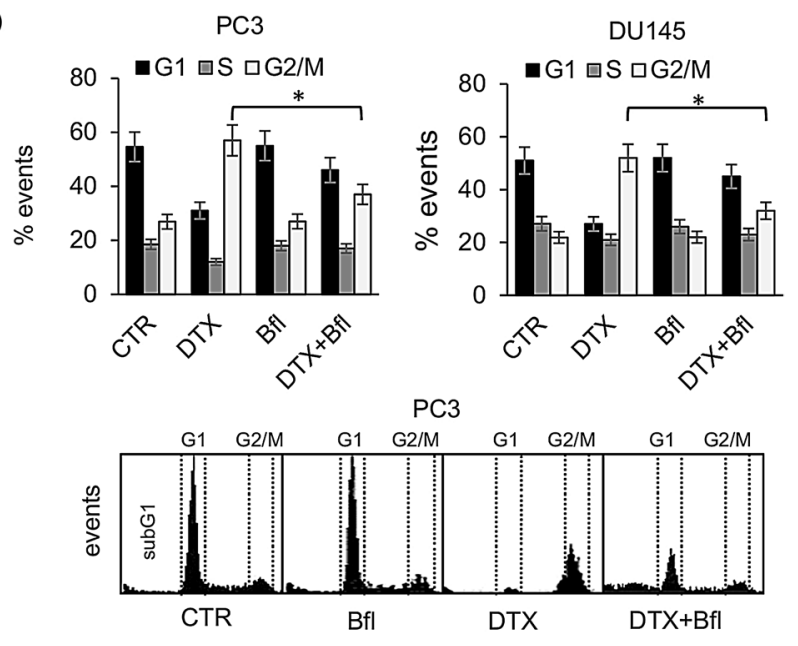

C

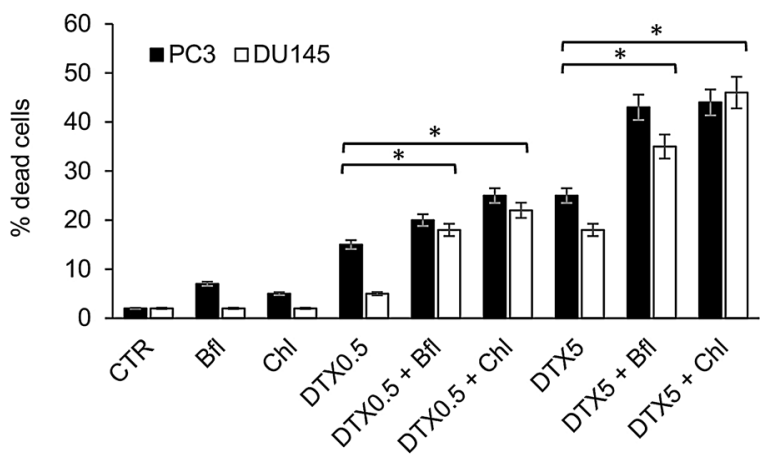

combination was not associated with an increased number of cells blocked in G2/M phase of the cell cycle, in fact the addition of bafilomycin and chloroquine to docetaxel stimulated a reduction in the number of cell in G2/M phase respect to docetaxel alone (Fig. 1b). At the same time, the measurement of the number of dead cells revealed that the increased antitumoral efficacy of the combination treatment was dependent on a higher capacity to induce cell death (Fig. 1c).

It is well known the capacity of docetaxel to induce the arrest in G2/M phase of the cell cycle and the concomitant 
a

\section{CTR \\ DTX \\ $\mathrm{DTX}+\mathrm{Chl}$}
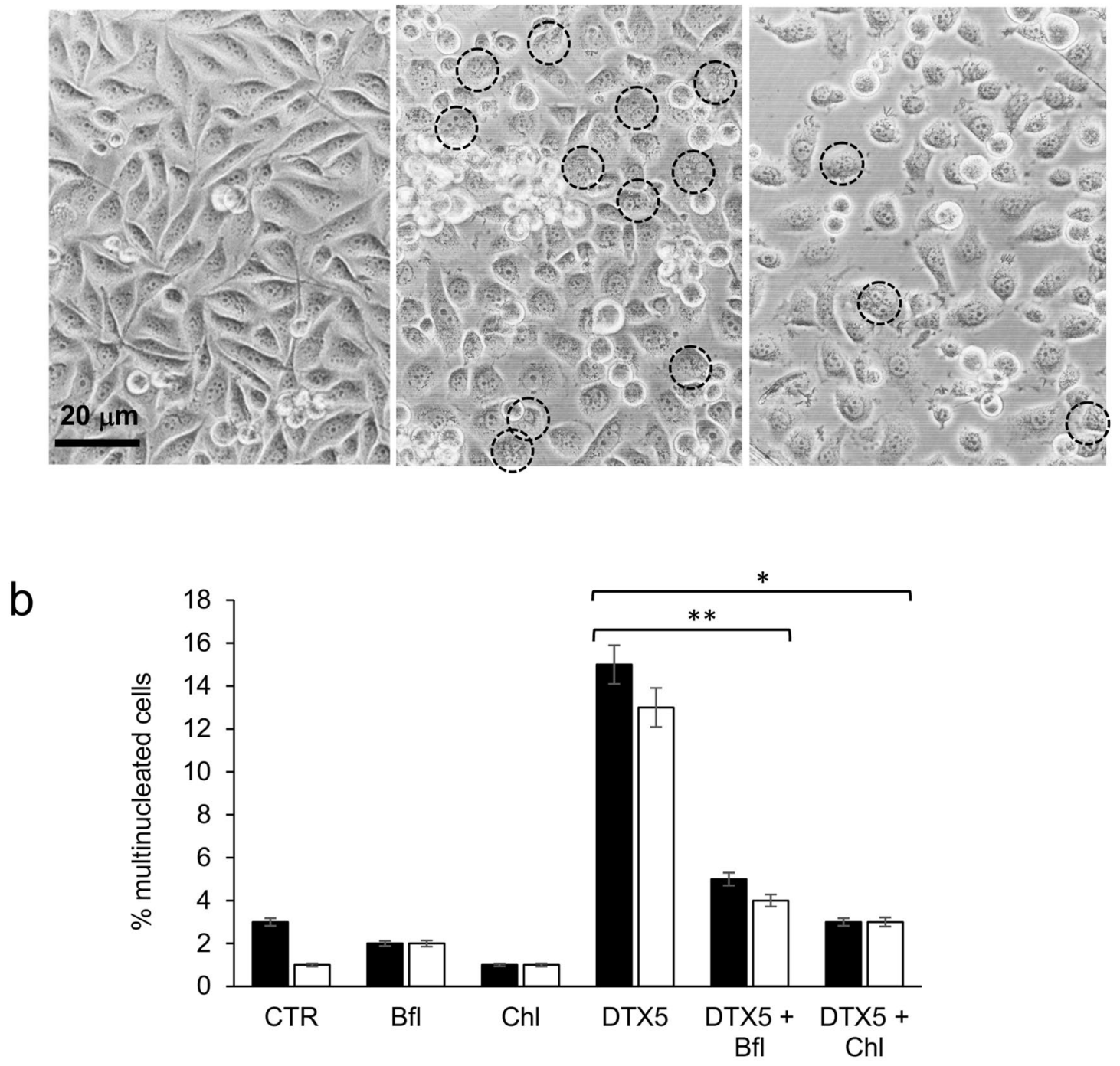

-PC3 口DU145

Fig. 2 PC3 and DU145 cells were treated for $72 \mathrm{~h}$ with $5 \mathrm{nM}$ docetaxel (DTX) alone or in combination with bafilomycin (Bfl $1 \mu \mathrm{M})$ or chloroquine $(20 \mu \mathrm{M})$, and then cells were observed with phasecontrast microscopy for the presence of multinucleated cells. a Exemplificative images of PC3 cells treated with DTX and chloroquine $(\mathrm{Chl})$, in which multinucleated cells were evidenced by black

emergence of multinucleated cells (Mittal et al. 2017). We confirmed this phenomenon in PC3 and DU145 cell lines and the appearance of multinucleated cells was well visible also by phase-contrast microscopy (Fig. 2a). After $72 \mathrm{~h}$ of treatment with $5 \mu \mathrm{M}$ docetaxel the percentage of multinucleated cells increased to about $15 \%$ and $13 \%$ in PC3 and DU145, respectively. The addition of bafilomycin circles. b The mean number of multinucleated cells for each experimental point was counted evaluating ten different optical fields with $40 \times$ magnification, and it was reported with SDs in the histogram. Asterisks indicate a statistically significant difference (Student's $t$ test, $p<0.05$ ) between number of multinucleated cells: (*) DTX5 + Chl vs DTX5; (**) DTX5 + Bfl vs DTX5

or chloroquine in docetaxel-treated cells counteracted significantly the formation of multinucleated cells, that were lower than $5 \%$ of the total number of cells (Fig. 2b). 
a

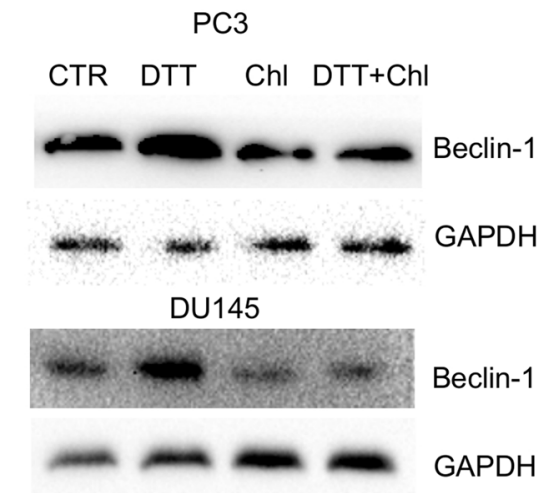

b

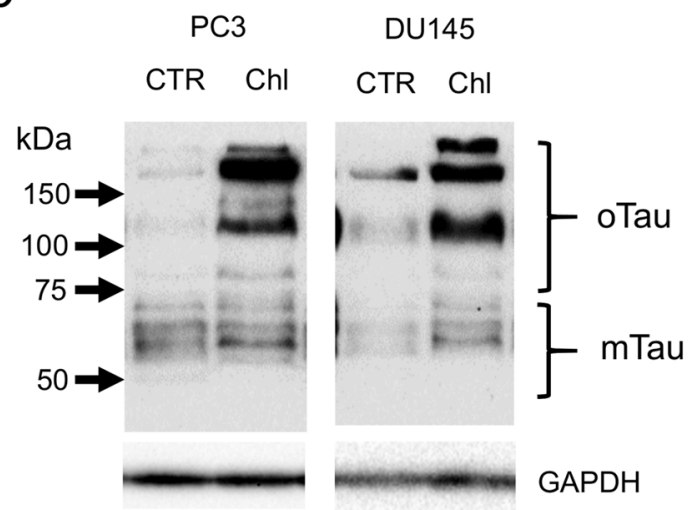

C

neg-CTR

CTR

Chl
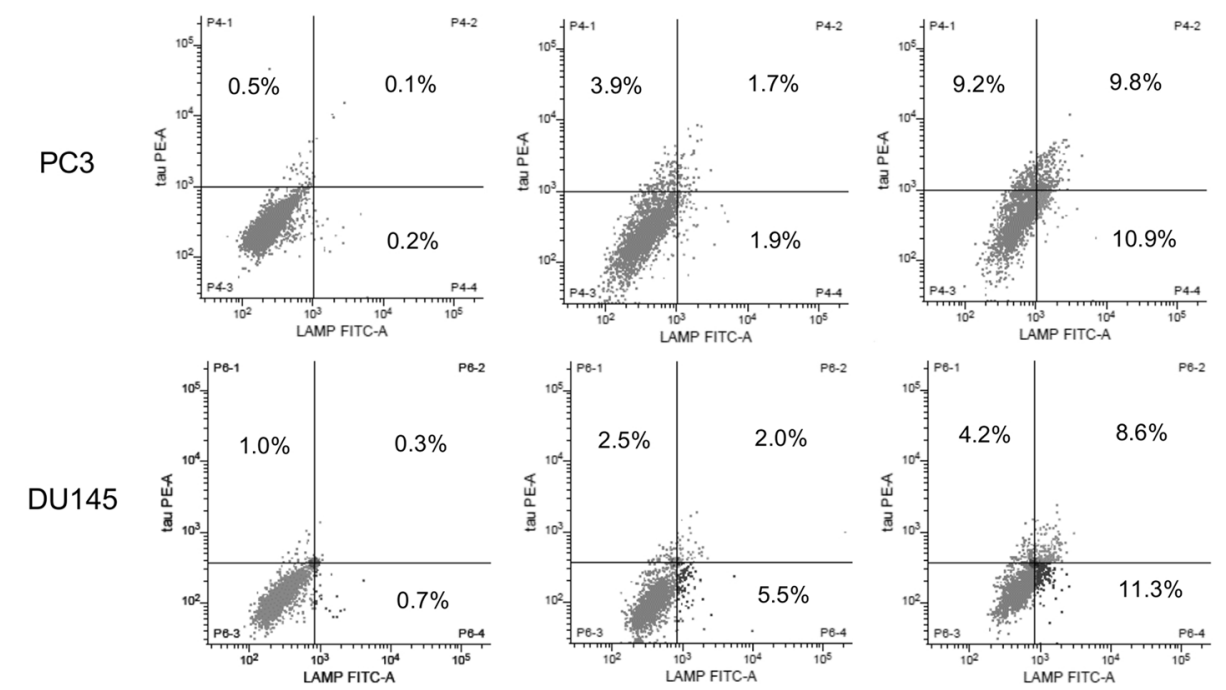

d

CTR

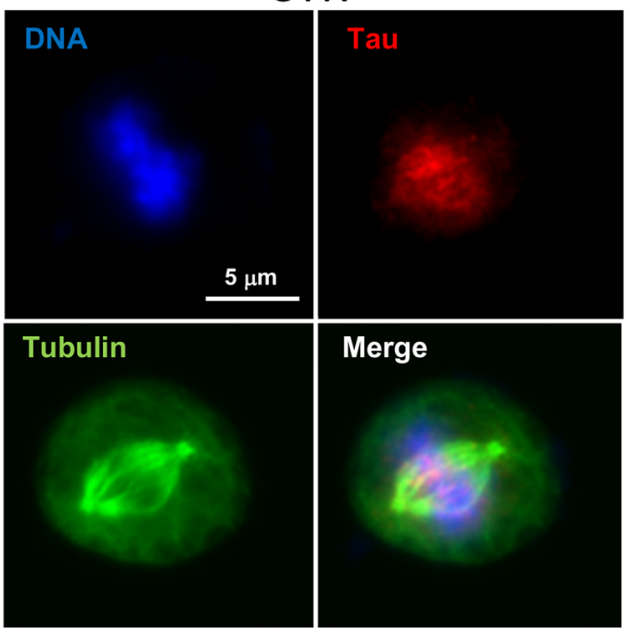

Chl

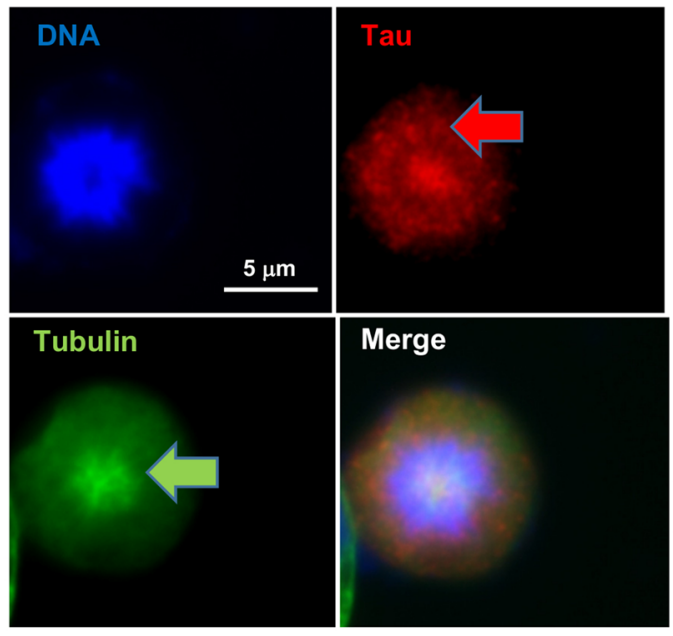


4 Fig. 3 a Beclin1 expression was analysed by western blot in PC3 and DU145 cells after $48 \mathrm{~h}$ treatment with $0.5 \mathrm{mM}$ DTT, $20 \mu \mathrm{M}$ chloroquine $(\mathrm{Chl})$, and combination $(\mathrm{DTT}+\mathrm{Chl})$. b The expression of tau was evaluated by western blot of total cell lysates from PC3 and DU145 cells treated with $20 \mu \mathrm{M}$ chloroquine for $72 \mathrm{~h}$. The complete pattern of immunodetection was shown with the indication of oligomeric (oTau) and monomeric tau forms (mTau) evinced by molecular weight. Expression of GAPDH from the same cell lysates was shown as a loading control. c Flow cytometry analysis of PC3 (upper panels) and DU145 (bottom panels) cells treated with $20 \mu \mathrm{M}$ chloroquine for $48 \mathrm{~h}$ and immunostained with anti-LAMP1 (FITC) and anti-tau (PE). The left panels show the fluorescence pattern of negative control cells (background fluorescence), and percentages of positive cells are indicated within each quadrant. d Tau expression was evaluated by immunofluorescence in PCa cells treated with $20 \mu \mathrm{M}$ chloroquine for $72 \mathrm{~h}$ and it was correlated with the pattern of DNA, stained with DAPI, and of immunodetected $\beta$-tubulin. Exemplificative images from control and chloroquine-treated PC3 cells showing in dividing cells the expression pattern of DNA (blue), tau (red) and $\beta$-tubulin (green). The fourth image for each series represents the digital combination (merge) of the previous three images taken by immunofluorescence microscopy. The arrows indicate the peculiar pattern of tau (red arrow) and $\beta$-tubulin (monoastral spindle, green arrow) in chloroquine-treated cells respect to control cells

\section{Inhibition of autophagy determines accumulation of tau oligomers}

DU145 cells are considered autophagy-resistant cells in some experimental conditions because they do not express ATG5. For this reason, we verified in these cells if autophagy was induced by endoplasmic-reticulum (ER) stress conditions. We treated PC3 and DU145 with $0.5 \mathrm{mM}$ DTT, a well-known ER-stress inducer, and verified the expression of beclin-1 (Fig. 3a). DTT treatment for $48 \mathrm{~h}$ determined the upregulation of beclin- 1 in both cell lines, while chloroquine was able to counteract this increment. In addition, the analysis of total cell lysates from PC 3 and DU145 cells treated with chloroquine revealed a shift in the relative abundance of different forms of tau protein. The western blot analysis permitted to detect several forms of tau protein that migrated with different molecular weights. According to the literature we can recognize as lower molecular weight forms (below $70 \mathrm{kDa}$ ) different isoforms due to alternative splicing and post-translational modification, whereas the higher molecular weight forms, above $70 \mathrm{kDa}$, are represented by soluble oligomers. The treatment with chloroquine determined an evident accumulation of tau protein, mainly as high-molecular weight oligomers in both PC3 and DU145 cell lines (Fig. 3b). To verify the concomitant accumulation of autophagy vesicles and tau protein we performed a double fluorescence immunostaining with antibodies antiLAMP1 and anti-tau in cells treated with chloroquine. The cells were analysed by flow cytometry and results showed that $24 \mathrm{~h}$ chloroquine treatment determined the up-regulation of LAMP1 and tau positive cells respect to untreated cells and that more than $50 \%$ of tau positive cells were also positive for LAMP1 (Fig. 3c). The analysis of cells by fluorescence microscopy for tau expression revealed a peculiar distribution of the positivity: in control cells the expression of tau was barely observable in the G1-phase cells, while tau become evident in M-phase cells with a clear association with the mitotic spindle (Fig. 3d). In cells treated with chloroquine we confirmed the positivity of cells in mitosis but in some cases with a different pattern of staining. In fact, tau was evident not only on the mitotic spindle but also in the cytoplasm. The concomitant analysis of $\beta$-tubulin in these cells revealed frequently an aberrant phenotype, e.g., monoastral spindle, associated with non-aligned chromosomes (Fig. 3d). This phenotype was interpreted as a consequence of any interference with the formation of the mitotic spindle.

\section{Formation of tau oligomers is associated with DNA damage and sensitization to docetaxel}

Then we evaluated whether the formation of the aberrant mitotic spindle and the inhibition of correct chromosome separation was associated with DNA damage. We treated PCa cells with docetaxel, chloroquine or their combination, and then analysed the expression of selected proteins, including cyclin b1, tau and $\mathrm{pH} 2 \mathrm{AX}$. The increase in cyclin b1 confirmed the G2/M block associated with docetaxel treatment (Fig. 4a). As expected, tau oligomers were particularly evident when cells were treated with chloroquine, and analysis of lysate from combination treatment showed that tau accumulation was stimulated by chloroquine also in presence of docetaxel. When we analysed $\mathrm{pH} 2 \mathrm{AX}$, which expression is associated with DNA double-strand breaks (DSBs), we observed an increase in the combination treatment, respect to single treatments and control. To localize on cells the expression of $\mathrm{pH} 2 \mathrm{AX}$, we performed an immunofluorescence analysis that revealed the association of $\mathrm{pH} 2 \mathrm{AX}$ with not segregated chromosomes in cells showing the aberrant mitotic spindle (Fig. 4b). To evaluate the role of tau oligomers in cooperation with docetaxel-induced cytotoxicity we chose a compound, methylene blue (BM), that was described as able to counteract the formation of tau aggregates in vitro and in vivo (Hosokawa et al. (2012)). We first confirmed by western blot analysis that BM inhibited the formation of tau oligomers induced by chloroquine (Fig. 5a). Then we added BM as pre-treatment, to PC3 and DU145 cells treated with docetaxel, chloroquine or their combination, and evaluated cell viability after $72 \mathrm{~h}$. BM was able to significantly revert the cytotoxicity increase due to the addition of chloroquine to docetaxel (Fig. 5b). Because BM exerted its effect without affecting in a significant manner the expression of monomeric tau forms, we aimed also to verify the possible role of these forms in the sensitivity to docetaxel. By siRNA-based interference method, tau expression was transiently silenced in cancer cells, reducing after $48 \mathrm{~h}$ the protein expression 
a

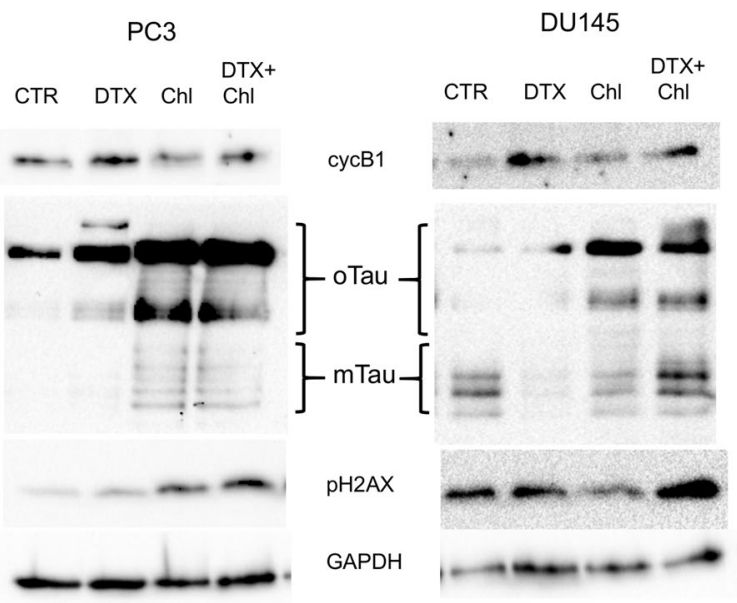

b

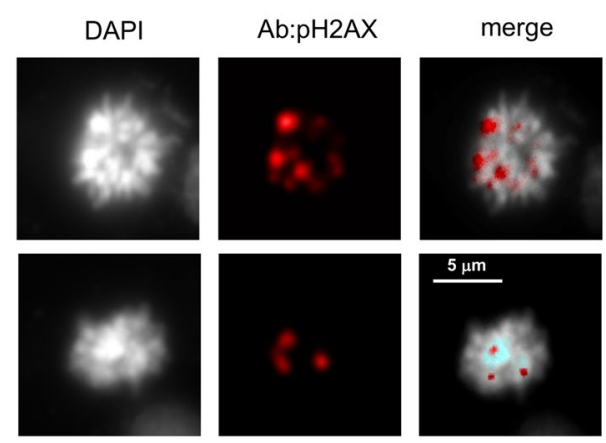

Fig. 4 Analysis of pH2AX expression in PCa cells treated with docetaxel and autophagy inhibitors. a PC 3 and DU145 cells were treated for $72 \mathrm{~h}$ with $5 \mathrm{nM}$ docetaxel alone or in combination with $20 \mu \mathrm{M}$ chloroquine, and then total lysates were analysed by western blot for the expression of selected markers: cyclin B1 (cycB1, marker of $\mathrm{G} 2 / \mathrm{M}$ cell cycle phase), tau (with the indication of oligomers and monomers) and $\mathrm{pH} 2 \mathrm{AX}$ (marker of DNA DSB). The expression of GAPDH was evaluated as loading control. b Sample images of aberrant mitotic PC3 cells treated with $5 \mathrm{nM}$ docetaxel in combination with $20 \mu \mathrm{M}$ chloroquine showing DNA content stained with DAPI (white) and pattern of immunodetected $\mathrm{pH} 2 \mathrm{AX}$ (red). A digital combination (merge) of the two previous images is shown to visualize the localization of DSB on DNA

of more than $80 \%$ respect to control cells (Fig. 6a). When tau-silenced cells were treated with docetaxel we observed after $48 \mathrm{~h}$ a reduction in the formation of giant hyperploid cells respect to control cells treated with the same docetaxel concentration (Fig. 6b). This phenomenon was paralleled by a significant reduction also in the viability of tau-silenced cells treated with docetaxel respect to control cells treated with docetaxel (Fig. 6c).

\section{Discussion}

Soluble tau oligomers of differing sizes have been reported in several studies. Using recombinant protein, dimers and trimers were observed in SDS-PAGE with apparent size greater than $100 \mathrm{kDa}$ (Patterson et al. 2011; Makrides et al. 2003; Lasagna-Reeves et al. 2010). These oligomers can be seeds for larger aggregates containing six to eight tau molecules (Sahara et al. 2007). The oligomers themselves have been shown to be toxic both in vitro and in vivo (LasagnaReeves et al. 2010, 2011). In addition, in neuroblastoma cell line SH-SY5Y, oligomers demonstrated a higher cytotoxic capacity with respect to tau monomers or filaments. Tau hyperphosphorylation and misfolding are the earliest disease-associated changes observed in tauopathies. Although many studies have demonstrated that dysregulation in tau phosphorylation is a common cause for the accumulation of pathologic tau oligomers (Alonso et al. 2001), other data indicate that tau aggregation was also phosphorylationindependent and that the formation of tau oligomers and/ or complexes with other proteins is determined by other post-translational modifications or simply by an excessive free cytosolic tau (Goedert et al. 1996). This phenomenon is confirmed by the evidence that tauopathies can be mimicked in many different models simply through the genetic hyperexpression or the addition of exogenous tau protein.

The mechanism underlying the toxic effect of tau oligomers is currently unknown, however available data and our results permit to speculate about a possible interference in the formation of the mitotic spindle. Indeed, since the observation of mitotic defects in tauopathies, association between tau and mitosis has represented an intriguing field of studies also in non-neuronal cells (Herrup 2010). Examples of dysfunction in microtubule association derived mainly from studies about specific mutated forms of tau. Mutations that compromised microtubules binding capacity or their assembly have been associated with aberrant mitotic spindle and chromosome missegregation. The initial observation of the presence of aneuploidy in peripheral cells of patients affected by neurodegeneration due to dominant mutation in tau seems to confirm in vivo a role of tau in genome stability (Rossi et al. 2008). In addition, there is a growing literature on aberrant cell cycle activation and re-entry, DNA damages and checkpoint activation in tauopathies (Khurana et al. 2012). Aberrant mitosis is also induced by WT tau, and in particular in association with overexpression/accumulation. It has been reported that 4R-Tau isoform overexpression in Drosophila wing discs induced the formation of monopolar spindles leading to aneuploidy and cell death also in non-neuronal cells (Bougé and Parmentier 2016). Similar phenomena were described by other authors in the development of Drosophila larval brains, with an increased level 
Fig. 5 Effect of methylene blue (BM) in docetaxel and combination-treated PCa cells. a The expression of tau oligomers was evaluated by western blot of total lysates from PC3 cells treated with $20 \mu \mathrm{M}$ chloroquine alone or in combination with $10 \mu \mathrm{M}$ BM for $72 \mathrm{~h}$. The complete pattern of immunodetection was shown with the indication of oligomeric (oTau) and monomeric tau forms (mTau) evinced by molecular weight. Expression of GAPDH from the same cell lysates was shown as a loading control. b PC3 and DU145 cells were treated for $72 \mathrm{~h}$ with $5 \mathrm{nM}$ docetaxel alone or in combination with $20 \mu \mathrm{M}$ chloroquine (black bar); the same experimental series were performed in presence of $10 \mu \mathrm{M}$ $\mathrm{BM}$ (white bar); the number of viable cells was measured and the means of five different experiments with SDs are reported in the histogram. When present, the statistical significant differences (Student's $t$ test, $p<0.05)$ between BM-treated and respective $\mathrm{BM}$-untreated cells are indicated in the graph by asterisk

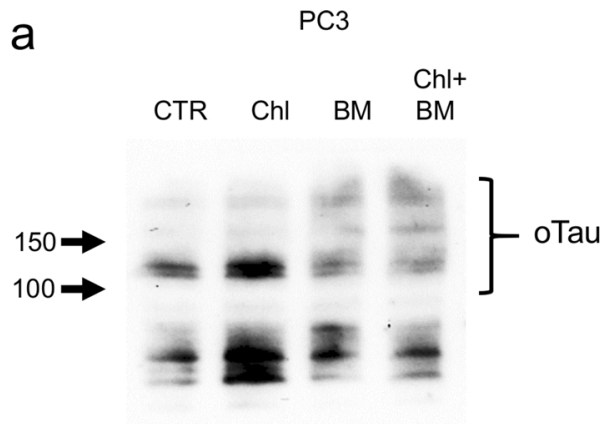

GAPDH

b

PC3

DU145

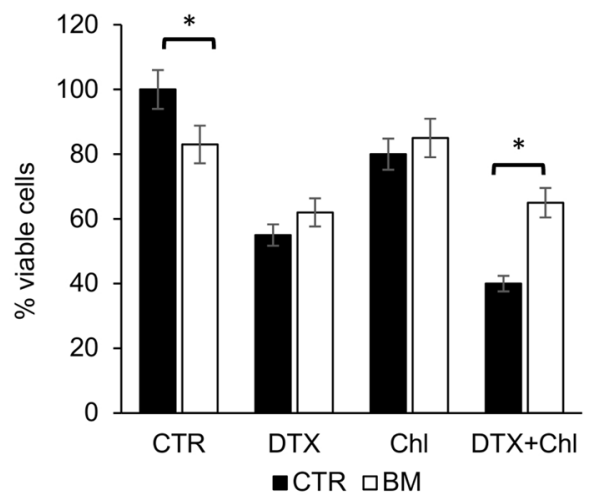

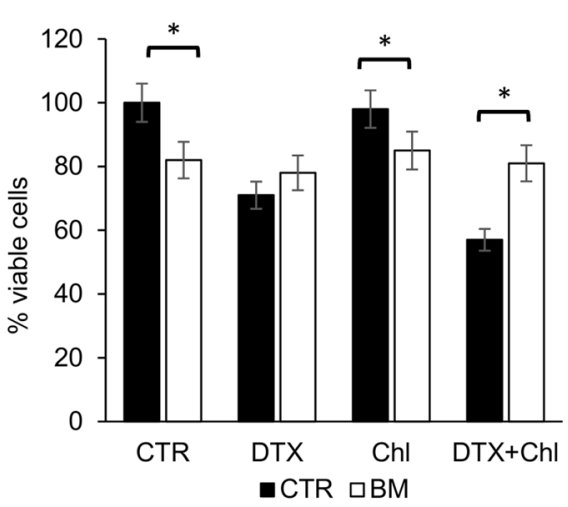

of aneuploidy. Importantly the same authors described the formation of monopolar spindles when WT or mutant tau were overexpressed in neuroblastoma cell line SH-SY5Y (Malmanche et al. 2017). Our data confirmed that accumulation of tau in the cytoplasm of mitotic cells is associated with the formation of monopolar spindles, both in control and docetaxel treated cells and this suggests the existence of a specific molecular mechanism interfering with the formation of the mitotic spindle.

Although tau overexpression, and in particular of high molecular weight isoforms, seems to be sufficient to induce mitotic defects, current knowledge does not permit to precisely describe the mechanism determining the antimitotic effect of tau. Tau is known to be hyperphosphorylated during mitosis and to localize to the mitotic spindle (Connolly et al. 1977). An interaction between 4R-Tau and the motor kinesin Kip69F (kinesin-5) during mitosis was described. Importantly Bougè and Parmentier demonstrated that excess of human tau protein inhibited the Eg5 kinesin and cell mitosis in Drosophila (Bougé and Parmentier 2016). In addition, imaging studies of kinesin motor proteins, kinesin 1 and Eg5, moving along microtubules showed that the binding of tau tended to block their motor activity. In particular, an alteration in tau availability can compromise the proper organization and stability of spindle microtubules (Dixit et al. 2008; Ma et al. 2011). The microtubule-binding protein MAP4, paralog of tau, has a similar negative effect on mitosis, and when transiently expressed in different human haematological cancers, MAP4 induced mitotic arrest with the presence of monopolar spindles (Holmfeldt et al. 2003). The fact that antimitotic effect of tau was only sporadically reported when transfected in cells could be due to the efficient clearance mechanism or alternative pathways. Indeed, in our experiments the most visible cytotoxic effect of tau oligomers was revealed with the concomitant inhibition of autophagy and the presence of mitotic stress. Otherwise, in basal conditions, we observed only a few aberrant mitotic figures, associated probably to phenotypic cancer heterogeneity. In agreement, Li et al. observed a slight but significant increase in G2/M phase in HEK293 cells transfected with the 1N3R Tau isoform ( $\mathrm{Li}$ et al. 2015).

Another hypothesis is that tau soluble oligomers can interact and change the localization of other proteins involved in mitosis. In fact, tau has been shown to localize in many intracellular districts other than cytoskeleton and there is evidence to support the hypothesis that post-translational 
a

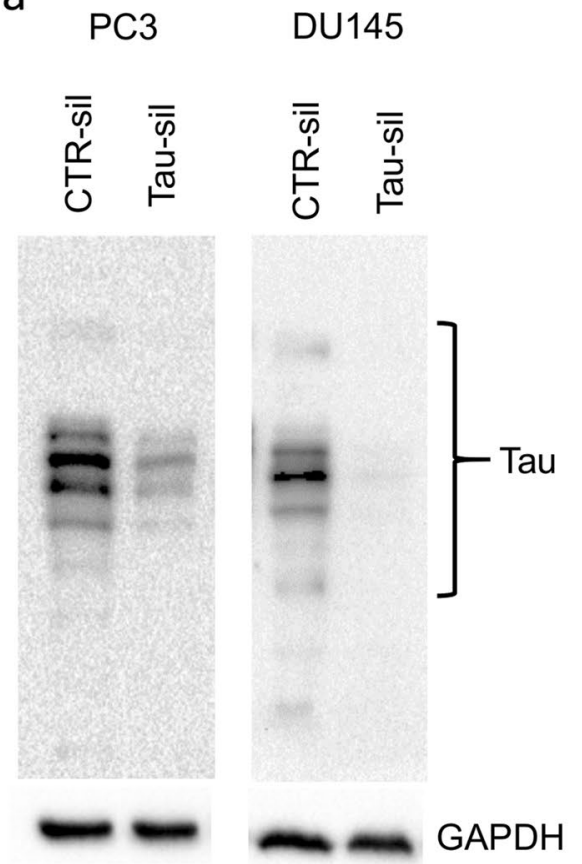

b

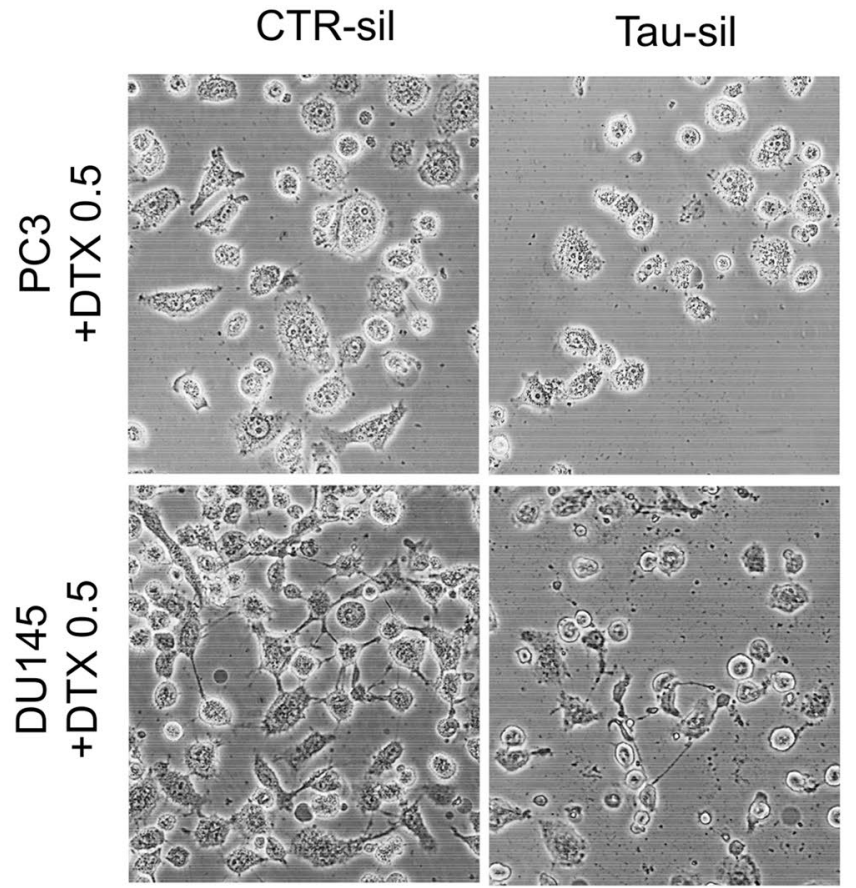

C

PC3

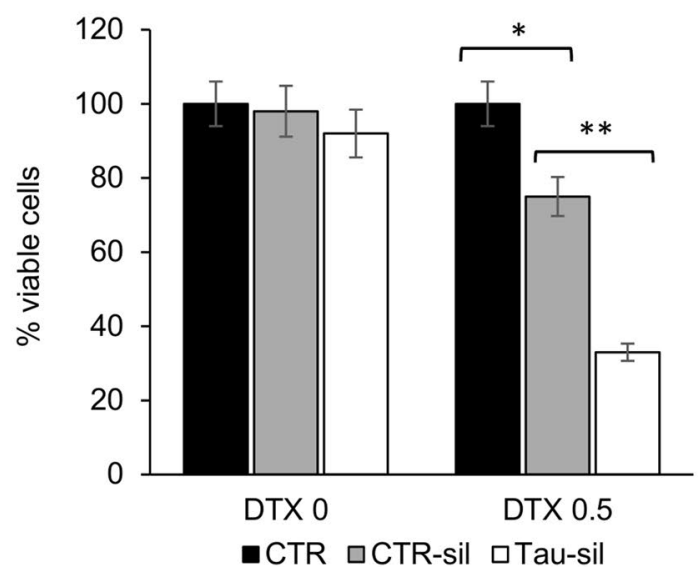

Fig. 6 Short-term Tau silencing was obtained in prostate cancer cells by siRNA interfering method. a The expression of tau was evaluated by western blot of total lysates collected from PC3 (left) and DU145 (right) $48 \mathrm{~h}$ after transfection with tau-targeted siRNA (tausil) or control random siRNA (CTR-sil). The expression of GAPDH was evaluated as loading control. b Tau-silenced and CTR-silenced PC3 and DU145 cells were treated for $48 \mathrm{~h}$ with $0.5 \mathrm{nM}$ docetaxel (DTX) and then cells were observed with phase-contrast microscopy for the presence of multinucleated giant cells. Exemplificative images

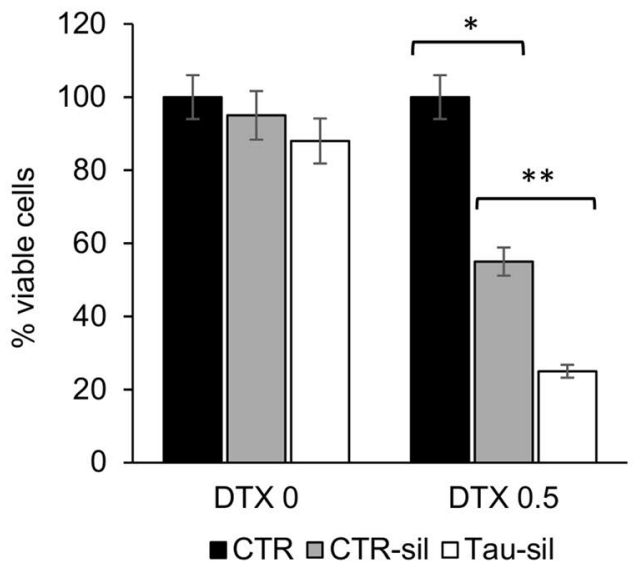

of tau-silenced and CTR-silenced cells treated with DTX are shown. c The same experimental series were analysed for the presence of viable cells, and the means of five different experiments with SDs are reported in the histogram. CTR indicates untreated cells. The presence of statistical significant differences (Student's $t$ test, $p<0.05$ ) are indicated in the graph by asterisk: (*) CTR vs DTX-treated CTRsilenced cells; (**) DTX-treated CTR-silenced vs DTX-treated tausilenced cells 
modifications can modulate its localization and function. For example, tau interacts with several kinases and phosphatases that have oncogenic potential (Mandelkow and Mandelkow 2012). Several ribonucleoprotein complexes (RNPs) can form toxic granules containing tau (Maziuk et al. 2017) and the overexpression of exogenous tau oligomers is sufficient to induce changes in localization and function of Musashi1 RBP in a dose dependent-manner (Montalbano et al. 2019). Also, tau may shuttle between cytoplasm and nucleus, as canonical heat-shock proteins do when they induce the stress response and, interacting with RNA and DNA, it can protect the neuron from senescence (Ulrich et al. 2018).

In addition, tau could also interact directly with chromosomes and protect them during mitotic segregation. Tau was detectable in nucleus and its presence contributes to maintain DNA double helix structure and DNA winding (Greenwood and Johnson 1995; Hua and He 2003; Frost et al. 2014). The in vivo genetic ablation of tau determined the accumulation of DNA breaks in specific DNA regions and in particular in pericentromeric chromatin (Mansuroglu et al. 2016). More than a structural protein, tau is considered a guardian of DNA, playing a role during cellular stress, when it was shown to translocate to the nucleus, preventing stress-induced DNA breaks (Sultan et al. 2011). The protective function by tau was well described under mild oxidative stress conditions, whereas pathological oxidative stress conditions lead to the formation of toxic tau oligomers. Interestingly, the same authors noted that hyperthermia induced a strong increase in $\gamma-\mathrm{H} 2 \mathrm{AX}$ foci selectively in KOtau neurons suggesting a direct role of tau in the DNA DSB repair in vivo (Violet et al. 2014; Violet et al. 2015). In our experiments we observed that the concomitant inhibition of autophagy and docetaxel treatment stimulate the formation of DNA DSBs, suggesting a direct association between DNA integrity and tau accumulation. Stimulatingly, DNA DSBs were evident in aberrant mitotic figures, and thus this renders plausible that DNA damage is a consequence of the toxic effect of tau oligomers on the formation of mitotic spindle rather than a direct effect on DNA integrity. These studies clearly highlighted the existence of critical time frames, after stress injury or during mitosis, during which monomeric tau can play a nucleic acid protective function. Thus, events triggering tau oligomerization, with the loss of the monomeric form, could render more vulnerable DNA to stress-induced damages. Oxidative stress is a basal characteristic of many cancers, and also an inducer of tau oligomerization, therefore protective mechanisms able to remove tau oligomers, such as autophagy, are fundamental in assuring cancer cell survival.

Cancer is frequently associated with chromosome aberrations, including polyploidy and aneuploidy, thus it is questionable whether tau could play a role in carcinogenesis or tumor progression (Giam and Rancati 2015). Although cancer cells show resistance to polyploidy, the continuous mitotic failure can induce programmed cell death, necrosis or senescence (Vitale et al. 2011a). A probable event seen in cancer cells in presence of unrepairable genomic instability is mitotic catastrophe (MC). Although the high degree of variability in $\mathrm{MC}$ does not permit to precisely characterize the molecular pathways involved, the leading event associated with this onco-suppressive event is the interference with the spindle assembly checkpoint that controls proper attachment of the chromosomes to the spindle microtubules, thus stimulating impaired segregation of genetic material between daughter cells, chromosomal breaks, clumps of chromatin and deficient karyokinesis (Castedo et al. 2004; Vitale et al. 2011b). The reduced number of multinucleated cells we observed in presence of autophagy inhibitors respect to docetaxel alone suggests that a fast permanence in $\mathrm{M}$ phase could be a protective mechanism against docetaxel toxicity. It is plausible that tau can protect from MC sustaining correct formation of mitotic spindle and segregation of chromosomes, allowing the bypass of the spindle assembly checkpoint. Microtubule inhibitors such as taxanes reduce dynamic turnover of mitotic spindle and activate spindle mitotic checkpoint, leading preferentially to MC. However, a possible outcome is also mitotic slippage in which occasionally cells could continue dividing without cytokinesis. Although the mechanisms that determine the fate of individual cells cannot be predetermined, it is plausible that molecular events that facilitate the exit from mitotic arrest are favourable for cancer survival. In this sense Inoue et al. suggested that autophagy may contribute to sensitization to chemotherapy by turning off spindle mitotic checkpoint and by shifting MC (Inoue et al. 2014).

Increased autophagy is a hallmark of advanced malignancies and it is supposed to confer a selective advantage during aberrant cell proliferation and in adverse microenvironmental conditions (Galluzzi et al. 2015). Autophagy can act as either pro-death or pro-survival factor, depending on the stage of cancer and microenvironmental context considered, and this paradoxical aspect is evident also during therapeutic intervention. In fact, autophagy may enhance cancer therapy efficacy through the direct or indirect promotion of cell death, but it can also enhance chemoresistance (Chen et al. 2010). Although in mammalian cells autophagy has been implicated in the turnover of cytoplasmic content, involvement in homeostasis of nuclear components has also been observed. Autophagosomes containing nuclear components were observed in wild-type cells, and more frequently in cells with nuclear defects, including envelopathies and improper chromosome segregation (Park et al. 2009; RelloVarona et al. 2012). Autophagy is also important for the timely removal of aggregated forms of pathogenic proteins, including tau. The clearance of misfolded proteins is mainly mediated by chaperone-mediated autophagy (CMA) 
and macroautophagy. Autophagic inhibition by 3-methylamphetamine or chloroquine was shown to counteract tau clearance, leading to tau aggregation (Hamano et al. 2008). On the other hand, stimuli that activate autophagy, including rapamycin, was shown to inhibit the accumulation of tau aggregates in vivo (Rodriguez-Navarro and Cuervo 2010). In addition, autophagy has been shown to play a key role in sustaining cell survival during mitotic arrest and MC (Inoue et al. 2014; Maskey et al. 2013). Our data suggest that inhibition of autophagy in prostate cancer cells determine a little reduction of proliferation, significant in PC 3 cells, in basal conditions, and a significant additive cytotoxic effect when used in combination with docetaxel. Because docetaxel induced an intense block in G2/M phase of the cell cycle in our cell model, it is plausible that autophagy exerts a protective effect just during cell division. It is unclear how autophagy can play a protective role during mitotic arrest, however, there is evidence of p53-dependent mechanism able to stimulate cell death in parallel with inhibition of autophagy (Xiao et al. 2015). Significantly, both cell lines we used in our study express non-functional p53, allowing autophagy to function also in presence of docetaxel-induced DSBs, and accounting for a partial resistance to the therapy.

The most consolidated evidence for tau involvement in cancer progression is currently represented by the predictive value of tau expression in breast and ovarian cancer. In prostate cancer, few data are available about a possible interaction between tau and taxanes treatment. Yang et al. demonstrated in the same cell lines used by us that inactivation of tau sensitized cancer cells to docetaxel toxicity. Interestingly these authors noted an upregulation of PI3K/ Akt/mTOR pathway in docetaxel resistant cells, suggesting a possible involvement of autophagy in the drug resistance (Yang et al. 2017). Other authors have confirmed the important role of autophagy as modulator of chemotherapy in prostate cancer, but also showing the dependence of this phenomenon on the cell model used (Cristofani et al. 2018). In fact, the mechanism underlying this clinically relevant aspect is largely unexplored. We propose that autophagy can counteract docetaxel toxicity modulating the expression level of tau protein. Some authors have previously linked resistance to taxanes to competitive action with tau for the same tubulin-binding domain, proposing an antagonizing role for microtubule stabilization (Kar et al. 2003). At the same time silencing of tau led to a significant decrease of survival ability of carcinoma cells treated with paclitaxel (Gurler et al. 2015). We confirmed these results and propose that tau oligomer-associated toxicity is realized through the interference with the protective role of tau monomer during mitosis. In fact, our data seem to indicate that the cooperative role of tau oligomers with docetaxel-induced cytotoxicity could be mimicked by silencing tau expression. Thus, our hypothesis is that the accumulation of tau oligomers, that we reached through autophagy inhibition, determined the sequestration of tau monomers interfering in their physiological activity and promoting cancer cell death.

In conclusion, we confirm the importance of tau homeostasis in docetaxel sensitivity and extend this view proposing that not only the presence of tau can protect from docetaxel cytotoxicity but that accumulation of tau can cooperate with the antimitotic drug. We speculate that the overexpression of tau in cancer could confer a selective advantage, mainly in the stabilization of DNA and/or mitotic spindle, in cancer cells characterized by aberrant highly heterogeneous genetic background. However, the peculiar biology of tau, that implicates the equilibrium with oligomeric forms, whose activity seems prevalently cytotoxic, could represent an Achilles heel for the cancer cell. In fact, to avoid the formation of progressively aggregating toxic tau oligomers, cancer must maintain a high protein turnover, mainly during mitosis, through the activation of autophagic removal. According to this hypothesis the inhibition of autophagy, interfering with tau turnover, could represent an effective strategy to counteract the resistance to antimitotic agents.

Acknowledgements The authors wish to thank the ALCLI "Giorgio e Silvia" Association for their support. Samantha Sabetta is supported by MIUR with a doctoral fellowship within the National Operational Program for Research and Innovation (Programma Operativo Nazionale Ricerca e Innovazione 2014-2020, ref: DOT13SR6G7).

Author contributions All authors contributed to the study conception and design. Material preparation, data collection and analysis were performed by SM, LC, SS and PM. The first draft of the manuscript was written by AA and SM, and MB and VM revised critically the manuscript. All authors read and approved the final manuscript.

Funding Open access funding provided by Università degli Studi dell'Aquila within the CRUI-CARE Agreement. The study was supported by a financial contribution from the University of L'Aquila. This research was part of the project: "Ce.Ca.Re.P.: Center for Cancer Research and Prevention", funded by ALCLI "Giorgio e Silvia", a non-profit association.

\section{Declarations}

Conflict of interest The authors declare no conflicts of interest

Open Access This article is licensed under a Creative Commons Attribution 4.0 International License, which permits use, sharing, adaptation, distribution and reproduction in any medium or format, as long as you give appropriate credit to the original author(s) and the source, provide a link to the Creative Commons licence, and indicate if changes were made. The images or other third party material in this article are included in the article's Creative Commons licence, unless indicated otherwise in a credit line to the material. If material is not included in the article's Creative Commons licence and your intended use is not permitted by statutory regulation or exceeds the permitted use, you will need to obtain permission directly from the copyright holder. To view a copy of this licence, visit http://creativecommons.org/licenses/by/4.0/. 


\section{References}

Alonso A, Zaidi T, Novak M, Grundke-Iqbal I, Iqbal K (2001) Hyperphosphorylation induces self-assembly of tau into tangles of paired helical filaments/straight filaments. Proc Natl Acad Sci U S A 98:6923-6928

Bougé AL, Parmentier ML (2016) Tau excess impairs mitosis and kinesin-5 function, leading to aneuploidy and cell death. Dis Model Mech 9:307-319

Castedo M, Perfettini JL, Roumier T, Yakushijin K, Horne D, Medema R, Kroemer G (2004) The cell cycle checkpoint kinase Chk2 is a negative regulator of mitotic catastrophe. Oncogene 23:4353-4361

Castillo-Carranza DL, Guerrero-Muñoz MJ, Sengupta U, Hernandez C, Barrett AD, Dineley K, Kayed R (2015) Tau immunotherapy modulates both pathological tau and upstream amyloid pathology in an Alzheimer's disease mouse model. J Neurosci 35:4857-4868

Chen S, Rehman SK, Zhang W, Wen A, Yao L, Zhang J (2010) Autophagy is a therapeutic target in anticancer drug resistance. Biochim Biophys Acta 1806:220-229

Ciechanover A, Kwon YT (2015) Degradation of misfolded proteins in neurodegenerative diseases: therapeutic targets and strategies. Exp Mol Med 47:e147

Connolly JA, Kalnins VI, Cleveland DW, Kirschner MW (1977) Immunoflourescent staining of cytoplasmic and spindle microtubules in mouse fibroblasts with antibody to tau protein. Proc Natl Acad Sci U S A 74:2437-2440

Cristofani R, Montagnani Marelli M, Cicardi ME, Fontana F, Marzagalli M, Limonta P, Poletti A, Moretti RM (2018) Dual role of autophagy on docetaxel-sensitivity in prostate cancer cells. Cell Death Dis 9:889

Dixit R, Ross JL, Goldman YE, Holzbaur EL (2008) Differential regulation of dynein and kinesin motor proteins by tau. Science 319:1086-1089

Fitzpatrick AWP, Falcon B, He S, Murzin AG, Murshudov G, Garringer HJ, Crowther RA, Ghetti B, Goedert M, Scheres SHW (2017) Cryo-EM structures of tau filaments from Alzheimer's disease. Nature 547:185-190

Frost B, Hemberg M, Lewis J, Feany MB (2014) Tau promotes neurodegeneration through global chromatin relaxation. Nat Neurosci 17:357-366

Galluzzi L, Pietrocola F, Bravo-San Pedro JM, Amaravadi RK, Baehrecke EH, Cecconi F, Codogno P, Debnath J, Gewirtz DA, Karantza V, Kimmelman A, Kumar S, Levine B, Maiuri MC, Martin SJ, Penninger J, Piacentini M, Rubinsztein DC, Simon HU, Simonsen A, Thorburn AM, Velasco G, Ryan KM, Kroemer $G$ (2015) Autophagy in malignant transformation and cancer progression. EMBO J 34:856-880

Gargini R, Segura-Collar B, Sánchez-Gómez P (2019) Novel functions of the neurodegenerative-related gene Tau in cancer. Front Aging Neurosci 11:231

Giam M, Rancati G (2015) Aneuploidy and chromosomal instability in cancer: a jackpot to chaos. Cell Div 10:3

Goedert M, Jakes R, Spillantini MG, Hasegawa M, Smith MJ, Crowther RA (1996) Assembly of microtubule-associated protein tau into Alzheimer-like filaments induced by sulphated glycosaminoglycans. Nature 383:550-553

Greenwood JA, Johnson GV (1995) Localization and in situ phosphorylation state of nuclear tau. Exp Cell Res 220:332-337

Gurler H, Yu Y, Choi J, Kajdacsy-Balla AA, Barbolina MV (2015) Three-dimensional collagen type I matrix up-regulates nuclear isoforms of the microtubule associated protein tau implicated in resistance to paclitaxel therapy in ovarian carcinoma. Int $\mathrm{J}$ Mol Sci 16:3419-3433
Hamano T, Gendron TF, Causevic E, Yen SH, Lin WL, Isidoro C, Deture M, Ko LW (2008) Autophagic-lysosomal perturbation enhances tau aggregation in transfectants with induced wild-type tau expression. Eur J Neurosci 27:1119-1130

Herrup K (2010) The involvement of cell cycle events in the pathogenesis of Alzheimer's disease. Alzheimers Res Ther 2:13

Holmfeldt P, Brattsand G, Gullberg M (2003) Interphase and monoastral-mitotic phenotypes of overexpressed MAP4 are modulated by free tubulin concentrations. J Cell Sci 116:3701-3711

Hosokawa M, Arai T, Masuda-Suzukake M, Nonaka T, Yamashita M, Akiyama H, Hasegawa M (2012) Methylene blue reduced abnormal tau accumulation in P301L tau transgenic mice. PLoS ONE 7:e52389

Hua Q, He RQ (2003) Tau could protect DNA double helix structure. Biochim Biophys Acta 1645:205-211

Huda MN, Erdene-Ochir E, Pan CH (2017) Assay for phosphorylation and microtubule binding along with localization of Tau protein in colorectal cancer cells. J Vis Exp

Inoue T, Nakayama Y, Li Y, Matsumori H, Takahashi H, Kojima H, Wanibuchi H, Katoh M, Oshimura M (2014) SIRT2 knockdown increases basal autophagy and prevents postslippage death by abnormally prolonging the mitotic arrest that is induced by microtubule inhibitors. FEBS J 281:2623-2637

Jimeno A, Hallur G, Chan A, Zhang X, Cusatis G, Chan F, Shah P, Chen R, Hamel E, Garrett-Mayer E, Khan S, Hidalgo M (2007) Development of two novel benzoylphenylurea sulfur analogues and evidence that the microtubule-associated protein tau is predictive of their activity in pancreatic cancer. Mol Cancer Ther 6:1509-1516

Kar S, Fan J, Smith MJ, Goedert M, Amos LA (2003) Repeat motifs of tau bind to the insides of microtubules in the absence of taxol. EMBO J 22:70-77

Kaur J, Debnath J (2015) Autophagy at the crossroads of catabolism and anabolism. Nat Rev Mol Cell Biol 16:461-472

Kellogg EH, Hejab NMA, Poepsel S, Downing KH, DiMaio F, Nogales E (2018) Near-atomic model of microtubule-tau interactions. Science 360:1242-1246

Khurana V, Merlo P, DuBoff B, Fulga TA, Sharp KA, Campbell SD, Götz J, Feany MB (2012) A neuroprotective role for the DNA damage checkpoint in tauopathy. Aging Cell 11:360-362

Lasagna-Reeves CA, Castillo-Carranza DL, Guerrero-Muoz MJ, Jackson GR, Kayed R (2010) Preparation and characterization of neurotoxic tau oligomers. Biochemistry 49:10039-10041

Lasagna-Reeves CA, Castillo-Carranza DL, Sengupta U, Clos AL, Jackson GR, Kayed R (2011) Tau oligomers impair memory and induce synaptic and mitochondrial dysfunction in wild-type mice. Mol Neurodegener 6:39

Lasagna-Reeves CA, Castillo-Carranza DL, Sengupta U, Sarmiento J, Troncoso J, Jackson GR, Kayed R (2012) Identification of oligomers at early stages of tau aggregation in Alzheimer's disease. FASEB J 26:1946-1959

Li ZH, Xiong QY, Tu JH, Gong Y, Qiu W, Zhang HQ, Wei WS, Hou YF, Cui WQ (2013) Tau proteins expressions in advanced breast cancer and its significance in taxane-containing neoadjuvant chemotherapy. Med Oncol 30:591

Li L, Xu ZP, Liu GP, Xu C, Wang ZH, Li XG, Liu EJ, Zeng J, Chai DM, Yao WL, Wang JZ (2015) Expression of 1N3R-Tau isoform inhibits cell proliferation by inducing $\mathrm{S}$ phase arrest in $\mathrm{N} 2 \mathrm{a}$ cells. PLoS ONE 10:e0119865

Lo Cascio F, Puangmalai N, Ellsworth A, Bucchieri F, Pace A, Palumbo Piccionello A, Kayed R (2019) Toxic Tau oligomers modulated by novel curcumin derivatives. Sci Rep 9:19011

Ma N, Titus J, Gable A, Ross JL, Wadsworth P (2011) TPX2 regulates the localization and activity of Eg5 in the mammalian mitotic spindle. J Cell Biol 195:87-98 
Maclean KH, Dorsey FC, Cleveland JL, Kastan MB (2008) Targeting lysosomal degradation induces p53-dependent cell death and prevents cancer in mouse models of lymphomagenesis. J Clin Invest 118:79-88

Makrides V, Shen TE, Bhatia R, Smith BL, Thimm J, Lal R, Feinstein SC (2003) Microtubule-dependent oligomerization of tau. Implications for physiological tau function and tauopathies. J Biol Chem 278:33298-33304

Malmanche N, Dourlen P, Gistelinck M, Demiautte F, Link N, Dupont C, Vanden Broeck L, Werkmeister E, Amouyel P, Bongiovanni A, Bauderlique $\mathrm{H}$, Moechars D, Royou A, Bellen HJ, Lafont F, Callaerts P, Lambert JC, Dermaut B (2017) Developmental expression of 4-repeat-Tau induces neuronal aneuploidy in drosophila tauopathy models. Sci Rep 7:40764

Mandelkow EM, Mandelkow E (2012) Biochemistry and cell biology of tau protein in neurofibrillary degeneration. Cold Spring Harb Perspect Med 2:a006247

Mansuroglu Z, Benhelli-Mokrani H, Marcato V, Sultan A, Violet M, Chauderlier A, Delattre L, Loyens A, Talahari S, Bégard S, Nesslany F, Colin M, Souès S, Lefebvre B, Buée L, Galas MC, Bonnefoy E (2016) Loss of Tau protein affects the structure, transcription and repair of neuronal pericentromeric heterochromatin. Sci Rep 6:33047

Maskey D, Yousefi S, Schmid I, Zlobec I, Perren A, Friis R, Simon HU (2013) ATG5 is induced by DNA-damaging agents and promotes mitotic catastrophe independent of autophagy. Nat Commun 4:2130

Matrone MA, Whipple RA, Thompson K, Cho EH, Vitolo MI, Balzer EM, Yoon JR, Ioffe OB, Tuttle KC, Tan M, Martin SS (2010) Metastatic breast tumors express increased tau, which promotes microtentacle formation and the reattachment of detached breast tumor cells. Oncogene 29:3217-3227

Maziuk B, Ballance HI, Wolozin B (2017) Dysregulation of RNA binding protein aggregation in neurodegenerative disorders. Front Mol Neurosci 10:89

Menzies FM, Fleming A, Caricasole A, Bento CF, Andrews SP, Ashkenazi A, Füllgrabe J, Jackson A, Jimenez Sanchez M, Karabiyik C, Licitra F, Lopez Ramirez A, Pavel M, Puri C, Renna M, Ricketts T, Schlotawa L, Vicinanza M, Won H, Zhu Y, Skidmore J, Rubinsztein DC (2017) Autophagy and neurodegeneration: pathogenic mechanisms and therapeutic opportunities. Neuron 93:1015-1034

Mimori K, Sadanaga N, Yoshikawa Y, Ishikawa K, Hashimoto M, Tanaka F, Sasaki A, Inoue H, Sugimachi K, Mori M (2006) Reduced tau expression in gastric cancer can identify candidates for successful Paclitaxel treatment. Br J Cancer 94:1894-1897

Mittal K, Donthamsetty S, Kaur R, Yang C, Gupta MV, Reid MD, Choi DH, Rida PCG, Aneja R (2017) Multinucleated polyploidy drives resistance to Docetaxel chemotherapy in prostate cancer. Br J Cancer 116:1186-1194

Montalbano M, McAllen S, Sengupta U, Puangmalai N, Bhatt N, Ellsworth A, Kayed R (2019) Tau oligomers mediate aggregation of RNA-binding proteins Musashi1 and Musashi2 inducing Lamin alteration. Aging Cell 18:e13035

Park YE, Hayashi YK, Bonne G, Arimura T, Noguchi S, Nonaka I, Nishino I (2009) Autophagic degradation of nuclear components in mammalian cells. Autophagy 5:795-804

Patterson KR, Remmers C, Fu Y, Brooker S, Kanaan NM, Vana L, Ward S, Reyes JF, Philibert K, Glucksman MJ, Binder LI (2011) Characterization of prefibrillar Tau oligomers in vitro and in Alzheimer disease. J Biol Chem 286:23063-23076

Piras A, Collin L, Grüninger F, Graff C, Rönnbäck A (2016) Autophagic and lysosomal defects in human tauopathies: analysis of post-mortem brain from patients with familial Alzheimer disease, corticobasal degeneration and progressive supranuclear palsy. Acta Neuropathol Commun 4:22
Rello-Varona S, Lissa D, Shen S, Niso-Santano M, Senovilla L, Marino G, Vitale I, Jemaa M, Harper F, Pierron G, Castedo M, Kroemer G (2012) Autophagic removal of micronuclei. Cell Cycle $11: 170-176$

Rodriguez-Navarro JA, Cuervo AM (2010) Autophagy and lipids: tightening the knot. Semin Immunopathol 32:343-353

Rossi G, Dalprà L, Crosti F, Lissoni S, Sciacca FL, Catania M, Di Fede G, Mangieri M, Giaccone G, Croci D, Tagliavini F (2008) A new function of microtubule-associated protein tau: involvement in chromosome stability. Cell Cycle 7:1788-1794

Rossi G, Redaelli V, Contiero P, Fabiano S, Tagliabue G, Perego P, Benussi L, Bruni AC, Filippini G, Farinotti M, Giaccone G, Buiatiotis S, Manzoni C, Ferrari R, Tagliavini F (2018) Tau mutations serve as a novel risk factor for cancer. Cancer Res 78:3731-3739

Rouzier R, Rajan R, Wagner P, Hess KR, Gold DL, Stec J, Ayers M, Ross JS, Zhang P, Buchholz TA, Kuerer H, Green M, Arun B, Hortobagyi GN, Symmans WF, Pusztai L (2005) Microtubuleassociated protein Tau: a marker of paclitaxel sensitivity in breast cancer. Proc Natl Acad Sci U S A 102:8315-8320

Sahara N, Maeda S, Murayama M, Suzuki T, Dohmae N, Yen SH, Takashima A (2007) Assembly of two distinct dimers and higher-order oligomers from full-length tau. Eur J Neurosci 25:3020-3029

Schroeder C, Grell J, Hube-Magg C, Kluth M, Lang D, Simon R, Höflmayer D, Minner S, Burandt E, Clauditz TS, Büscheck F, Jacobsen F, Huland H, Graefen M, Schlomm T, Sauter G, Steurer $S$ (2019) Aberrant expression of the microtubule-associated protein tau is an independent prognostic feature in prostate cancer. BMC Cancer 19:193

Shafiei SS, Guerrero-Muñoz MJ, Castillo-Carranza DL (2017) Tau oligomers: cytotoxicity, propagation, and mitochondrial damage. Front Aging Neurosci 9:83

Silva JM, Rodrigues S, Sampaio-Marques B, Gomes P, Neves-Carvalho A, Dioli C, Soares-Cunha C, Mazuik BF, Takashima A, Ludovico P, Wolozin B, Sousa N, Sotiropoulos I (2019) Dysregulation of autophagy and stress granule-related proteins in stress-driven Tau pathology. Cell Death Differ 26:1411-1427

Smoter M, Bodnar L, Grala B, Stec R, Zieniuk K, Kozlowski W, Szczylik C (2013) Tau protein as a potential predictive marker in epithelial ovarian cancer patients treated with paclitaxel/platinum first-line chemotherapy. J Exp Clin Cancer Res 32:25

Souter S, Lee G (2009) Microtubule-associated protein tau in human prostate cancer cells: isoforms, phosphorylation, and interactions. J Cell Biochem 108:555-564

Sultan A, Nesslany F, Violet M, Bégard S, Loyens A, Talahari S, Mansuroglu Z, Marzin D, Sergeant N, Humez S, Colin M, Bonnefoy E, Buée L, Galas MC (2011) Nuclear tau, a key player in neuronal DNA protection. J Biol Chem 286:4566-4575

Ulrich G, Salvadè A, Boersema P, Calì T, Foglieni C, Sola M, Picotti P, Papin S, Paganetti P (2018) Phosphorylation of nuclear Tau is modulated by distinct cellular pathways. Sci Rep 8:17702

Vinod V, Padmakrishnan CJ, Vijayan B, Gopala S (2014) 'How can I halt thee?' The puzzles involved in autophagic inhibition. Pharmacol Res 82:1-8

Violet M, Delattre L, Tardivel M, Sultan A, Chauderlier A, Caillierez R, Talahari S, Nesslany F, Lefebvre B, Bonnefoy E, Buée L, Galas MC (2014) A major role for Tau in neuronal DNA and RNA protection in vivo under physiological and hyperthermic conditions. Front Cell Neurosci 8:84

Violet M, Chauderlier A, Delattre L, Tardivel M, Chouala MS, Sultan A, Marciniak E, Humez S, Binder L, Kayed R, Lefebvre B, Bonnefoy E, Buée L, Galas MC (2015) Prefibrillar Tau oligomers alter the nucleic acid protective function of Tau in hippocampal neurons in vivo. Neurobiol Dis 82:540-551 
Vitale I, Galluzzi L, Castedo M, Kroemer G (2011a) Mitotic catastrophe: a mechanism for avoiding genomic instability. Nat Rev Mol Cell Biol 12:385-392

Vitale I, Galluzzi L, Senovilla L, Criollo A, Jemaà M, Castedo M, Kroemer G (2011b) Illicit survival of cancer cells during polyploidization and depolyploidization. Cell Death Differ 18:1403-1413

Wang Y, Mandelkow E (2016) Tau in physiology and pathology. Nat Rev Neurosci 17:5-21

Wang Q, Wang N, Shao G, Qian J, Shen D, Fei Y, Mao W, Wu D (2013) Relationship between gastric cancer tau protein expression and paclitaxel sensitivity. Pathol Oncol Res 19:429-435

Ward SM, Himmelstein DS, Lancia JK, Binder LI (2012) Tau oligomers and tau toxicity in neurodegenerative disease. Biochem Soc Trans 40:667-671

Wosnitzer MS, Domingo-Domenech J, Castillo-Martin M, Ritch C, Mansukhani M, Petrylack DP, Benson MC, McKiernan JM, Cordon-Cardo C (2011) Predictive value of microtubule associated proteins tau and stathmin in patients with nonmuscle invasive bladder cancer receiving adjuvant intravesical taxane therapy. J Urol 186:2094-2100

Xiao J, Zhang T, Xu D, Wang H, Cai Y, Jin T, Liu M, Jin M, Wu K, Yuan J (2015) FBXL20-mediated Vps34 ubiquitination as a p53 controlled checkpoint in regulating autophagy and receptor degradation. Genes Dev 29:184-196

Yang J, Yu Y, Liu W, Li Z, Wei Z, Jiang R (2017) Microtubule-associated protein tau is associated with the resistance to docetaxel in prostate cancer cell lines. Res Rep Urol 9:71-77

Publisher's Note Springer Nature remains neutral with regard to jurisdictional claims in published maps and institutional affiliations. 